\title{
MARINE DEBRIS: GLOBAL AND REGIONAL IMPACTS
}

\author{
DESECHOS MARINOS: IMPACTOS GLOBALES Y REGIONALES
}

Daniel Torres N. ${ }^{1} \&$ Jorge Berguño B. ${ }^{2}(+)$

\section{RESUMEN}

Se presenta una síntesis sobre el problema de los desechos marinos, basándose en el conocimiento general sobre la materia y sobre la experiencia obtenida en cabo Shirreff, isla Livingston, Shetland del Sur, Antártica. Se sugiere mejorar la base de datos sobre los desechos marinos mediante la investigación científica permanente y con actividades de seguimiento. Es necesario coordinar las acciones con grupos claves de investigación sobre el tema para aplicar estrategias que permitan identificar tipos, fuentes, cantidades, interacciones y aspectos socioeconómicos de este problema global y regional. Se hace necesario desarrollar índices marinos con el propósito de compartir ampliamente el conocimiento e información acerca del problema de una forma transparente. El programa Global de Acción para la Protección del Ambiente Marino de Actividades Basadas en Tierra (GPA) tiene algunos objetivos relacionados con el problema de los desechos marinos que es necesario aplicar a todas las fuentes emisoras, basadas en la información proporcionada en forma cooperativa por diversas organizaciones relacionadas con el tema.

Se mencionan medidas para prevenir y reducir el impacto de los desechos marinos, especialmente considerando la particular naturaleza del medio marino y su vulnerabilidad. Se citan instrumentos legales internacionales incluyendo aquellos que se refieren al manejo de las basuras e infraestructura portuaria para la recepción de desechos de las naves. La educación y el conocimiento de las medidas de cuidado para reducir y prevenir futuros problemas sobre desechos marinos son temas clave, especialmente tomando en consideración los aspectos legales y la vulnerabilidad del Océano Austral. Se concluye que el CEP debería adoptar medidas para reducir el impacto de los desechos marinos en el ecosistema marino antártico, tales como solicitar a la IAATO que establezca un Código de Conducta revisado y actualizado para minimizar el problema; apoyar las iniciativas de la CCRVMA para mantener, mejorar y expandir

1 Facultad de Ciencias Agropecuarias, Campus Las Condes, Av. Apoquindo 5142, Universidad Pedro de Valdivia, Santiago, Chile.

2 Oficina de Coordinación del Instituto Antártico Chileno, Teatinos 180, 7ํ piso, Santiago, Chile.

+ Deceased on 7th May, 2011. 
las actividades de seguimiento de tales desechos en otros Sitios CEMP; recomendar el desarrollo de estrategias educativas sobre la base de aquellas establecidas por la APEC, CCRVMA; FAO, GPA, e incluir una sección especial en el Informe Final de las Reuniones Consultivas del Tratado Antártico, con el fin de enviarlas a la consideración del Secretario General de las NU como contribución a las discusiones que se deben considerar en las reuniones del Proceso Consultivo Informal de las NU sobre los océanos y la Ley del Mar.

Palabras clave: Desechos marinos, contaminación marina, CEP, RCTA, Antártica, UN.

\section{ABSTRACT}

A synthesis on the Marine Debris problem is given upon de basis of the general knowledge on the matter as well as that obtained at Cape Shirreff, Livingston Island, South Shetland, Antarctica. It is suggested to improve the database on marine debris through permanent scientific research as well as with monitoring activities. It is necessary to coordinate key groups to apply strategies to identify types, sources, amount, interactions and socio-economic aspects of this global and regional problem. It would be necessary to develop basic marine indices with the purpose to share a wide knowledge and information about the problem in a transparent way. The Global Programme of Action for the Protection of the Marine Environment from Land-Based Activities (GPA) has some objectives related to the marine debris problem that it is necessary to be applied to all sources, based on the information given by several organizations in a cooperative way.

Measurements to prevent and reduce the impact of marine debris are mentioned, especially taken into account the special nature of the marine environment and vulnerable condition. International legal instruments are cited, including waste management, facilities to garbage reception at ports. Education and awareness is a key aspect to reduce and prevent future marine debris problems, taking into account the legal aspects and vulnerability of the Southern Ocean. It is concluded that the CEP would adopt measures to reduce the impact in the Antarctic marine ecosystem, such as requesting to IAATO to establish a Code of Conduct to minimize the problem; to support the CCAMLR initiative to maintain, improve and expand the monitoring activities in other CEMP Sites; recommend the development of educational strategies upon the basis of APEC, CCAMLR, FAO, GPA; and include an especial section of the Final Report of the ATCM Meetings in order to be sent to the consideration of the UN Secretary General as a contribution to discussions to be held at the annual United Nations Open-ended Informal Consultative Process on Oceans and the Law of the Sea.

Key words: Marine debris, marine pollution, CEP, ATCM, Antarctica, UN.

\section{INTRODUCTION}

During centuries, human activities have deposited all kinds of waste into the waters of lakes, rivers and oceans. This behaviour persists until now in many parts of the world, producing environmental impacts with significant effects in wildlife, since at least 267 species of marine wildlife are being affected by debris; coastal and farming areas may also be affected, but the greater environmental harm includes physical damage to vulnerable habitats, such as covering of coral reefs, smothering of sea grass beds and seabed ecosystems recognised as important spawning and nursery grounds for fish and other marine species; human health is threatened by possible diseases caused by the presence of invisible pathogenic pollutants and other bacterial contamination; and navigational hazards (Torres, 1996) such as entanglement of vessel propellers and rudders, suffered by the Akebono Maru, a Japanese vessel fishing krill in the Southern Ocean, fortunately released with the help of tactical divers from the Chilean Navy's AP 45 Piloto Pardo. 
In many parts of the world a view at the sea level from the top of nearby mountains reveals the extent of marine pollution originated by waste produced by human activities, including negligent actions of tourists or developers of natural resources, such as living marine resources, or tourist operators exploiting the advantages of outstanding natural scenery.

Waste thrown out of the windows of passing vehicles may spread to all adjacent areas; plastic carried by water channels damages plants and cultivated fields; rivers transport the waste to the river mouth, neighbouring beaches and the sea; different types of activities in the oceans leave behind a stream of waste, best known as marine debris. Marine debris may be found sometimes quite close to the source of input, but can also be transported over long distances by ocean currents and winds.

Marine debris, also referred to as marine litter, is any persistent, manufactured or processed solid material discarded, disposed or abandoned in the marine or coastal environment. While urban debris is predominant in the vicinity of large cities, shipgenerated debris is a major contributor to marine pollution on distant coastlines.

Globally, marine debris is a visible, important indicator of human impact on the marine environment and a source of public concern, as it causes environmental, economic and health problems, and undermines aesthetic values.

While there are no recent and exact figures on the amount of marine debris worldwide, some estimates mention figures close to 8 million items of marine debris entering the oceans of the world every day.

Under the Convention for the Conservation of the Antarctic Marine Living Resources (CCAMLR), monitoring in $\mathrm{CEMP}^{3}$ sites since 1989 resulted in a fairly important gathering of data and conservation measures, as well as co-ordinated actions by Members (i.e.: Cape Shirreff, Livingston Island, South Shetland (Torres, 1990, 1992, 1996, 1997; Aguilera y Torres, 2004, 2005; Torres y Aguayo, 1993, Torres y Jorquera, 1994, 1995, 1996, 1998; Torres y Gajardo, 1985; Hucke-Gaete et al, 1997a y b). A significant decrease in the amount of garbage attaining the coast of sub-Antarctic islands, such

3 CCAMLR Environmental Monitoring Program. as South Georgia and the South Shetland Islands, was appreciated according to information provided at the CCAMLR Scientific Committee Meeting in October 2004 and 2005. The main sea-based sources of marine litter had been identified during this thirteen-year period as accidental, deliberate or routine discharges or dumping from various types of ships, pleasure craft, fishing and tourist vessels (Torres, 2001). An increase in tourist activity ordinarily yields a greater impact because larger vessels with many people on board generate considerable amounts of waste. Wastes dumped intentionally or cargo washed overboard can constitute marine debris. Shipping contributes between 10 to 20 per cent of the world's marine debris.

Commercial fishing activities introduce marine debris into the ocean through accidental loss of fishing gear or through intentional disposal of worn-out gear. Nets, gillnets, bottom long-lines and ropes, salt treatment bags, bait boxes, traps and pots, totes, fish and lobster tags, and trawls floats. Due to the resistance of modern synthetics to degradation, derelict fishing gear has been identified as the most biologically threatening of the debris categories. Entanglement and ingestion by fish, sea turtles, sea birds and especially marine mammals (Torres, 1990, Torres et al, 1996, 1997; Hucke-Gaete et al, 1997 a y b) as well as damage on marine benthic habitats are some of the most visible impacts of derelict fishing gear (PACON, 2000).

However, when comparisons of the accumulation of marine debris among different locations is envisaged, it becomes a complex operation due to the diversity in periods of study and in methods used to classify debris and beach substrate. These differences are greater when marine debris originates in land-based sources, as underlined in the document "Protecting the oceans from land-based activities" GESAMP (2001). In fact, land-based sources are extremely widespread, and include materials, manufacturers, processors and transporters. A major source is sewer overflows and sewage treatment plants. Legal and illegal shore-based solid waste management practices, both in coastal areas and along inland waterways, also contribute to the problem of marine debris. Land-based sources contribution to marine debris can be assessed at 60 to 80 per cent.

Although anthropogenic activity on land and sea is the main cause for the presence of marine 
debris, natural phenomena may also have a role in their creation. The Indian Ocean tsunami, in addition to the tremendous loss to human life and property, produced enormous amounts of debris that ended up in the marine environment, with further physical damage to already damaged vulnerable ecosystems. Tsunami-generated waste poses a risk to human health as well as to ecological functions. Posttsunami environmental assessments demonstrated that the protective or natural buffers entrenched in coastal systems had been weakened by unsustainable economic development, in particular tourism and aquaculture, and could not provide a shield against the destructive force of the tsunami except in areas of extensive reefs.

In order to address the significant gaps in our knowledge about the global marine debris situation and the uneven geographically distributed information, it is imperative to improve and consolidate the information base on marine debris through further research and monitoring activities. Strategies for identifying types, sources, amounts, interactions, socio-economic aspects and key user-groups are needed. Basic marine indicators should be developed so that data and information about quantities and trends in marine debris become a transparent and widely shared knowledge. State of the Environment Reports, on a global and regional basis, should include marine debris as a source of serious concern. The Global Programme of Action for the Protection of the Marine Environment from Land-Based Activities (GPA) contains a number of objectives in relation to marine litter and possesses a Clearing-House node (Global Marine Litter Information Gateway) which is focused on land-based sources and targets sewage, POPs, radioactive substances, heavy metals, oil, nutrients, sediments, litter and physical alterations/ destruction of habitats, but could be adapted to the spreading of information an all sources of marine debris based on information provided by interested organizations on a cooperative basis.

Measures to prevent and reduce the impact of marine debris

A distinction should be made between measures that are aimed at preventing and reducing marine debris at source and those that need to be taken to deal with debris from the moment it is found in the marine and coastal environment. This paper does not deal with the second type of measures, as they are qualified by the diverse nature of the damaged environments and by different requirements for the many areas, activities and actors involved in each case. Examples of global cleanup operations include the International Coastal Cleanup (ICC) and Clean Up the World, undertaken with significant costs (Sheavly, 2004). However, cleanup and restoration measures are generally tasked to local authorities, volunteers and NGOs and must take into account the particular conditions of the relevant area. The special nature of the Antarctic Marine Environment and its vulnerable condition shall be examined in this context.

Measures to prevent and reduce marine debris include (a) compliance with and effective implementation of international instruments (b) better waste management on land and at sea, including through improved recycling of materials and development of biodegradable packaging materials; (c) enhancing of port reception facilities; and (d) education and awareness-raising activities to influence the behaviour of the relevant actors.

\section{Legal Instruments}

Although marine debris is not always specifically mentioned in international legal instruments, many of them contain the obligation to decrease or eliminate the discharge of ship-generated waste, or measures to stop the discharge of solid waste from land-based sources, or action to reduce the loss of fishing gear from fishing vessels, in ways that implicitly cover the issue of marine debris. The following instruments are applicable at a global or regional level:

1. UNCLOS. Part XII of the 1982 United Nations Convention for the Law of the Sea sets out the duties of States to protect and preserve the marine environment.

2. MARPOL 73/78. The international rules and standards for the prevention, reduction and control of pollution from vessels referred to in UNCLOS are mainly contained in MARPOL 73/78, which regulates discharges from ships in its six Annexes.

3. London Convention 1972. The Convention on the Prevention of Marine Pollution by Dumping 
of Wastes and other prohibits the disposal at sea of anything that may lead to marine debris. It will be replaced by the Protocol, which prohibits all dumping, except for a list of non-hazardous materials that may be dumped subject to environmental assessments.

4. Basel Convention. The Basel Convention would be applicable to marine debris provided such debris falls under its scope and is listed under its Annexes, which are under constant review.

5. The Convention on Biological Diversity (CBD). In the context of the Jakarta Mandate on Marine and Coastal Biodiversity, the issue of marine litter is included within the scope of activities dealing with coastal and marine pollution.

6. The Agreement on the Conservation of Albatrosses and Petrels (ACAP). The problem of marine debris is specifically referred to in the Action Plan contained in Annex II.

7. FAO Code of Conduct for Responsible Fisheries. The 1995 Code requires that fishing be conducted with due regard to the protection of the marine environment and encourages technologies and methods to minimise the loss of fishing gear and the ghost fishing effects of lost or abandoned fishing gear.

8. Global Programme of Action for the Protection of the Marine Environment from Land-Based Activities (GPA). The GPA adopted in November 1995 considers the establishment of facilities for receiving, handling and disposing of litter from coastal communities; the reduction of the amount of litter reaching the coastal and marine environments, and the improvement of waste management practices.

9. Agenda 21 and the Johannesburg Plan of Implementation. Calls on States to facilitate the establishment of port reception facilities, to address the prevention and minimisation of waste and the maximisation of reuse, to ratify and implement conventions dealing with marine pollution from shipping, and apply the GPA.

10. UNEP Regional Seas Programmes (RSP). These programmes established in the mid-1970's and the regional Action Plans developed accordingly support the prevention and reduction of marine debris. In some regions, such as the South-East Pacific, the protection of the marine environment has been further enhanced by the adoption of specific protocols on the protection of the marine environment against pollution by land-based sources or by dumping, providing a more targeted approach to the problem of marine debris.

\section{Waste management}

Diminishing the generation of waste on land, onboard ships, fishing and research vessels, pleasure craft, offshore platforms, inter alia by reusing and recycling materials. Large vessels and offshore platforms should have waste management plans and preparations for proper waste management should also include yachts, smaller vessels and pleasure craft. Members of the International Council of Cruise Lines (ICCL) adopted in 2001 the Cruise Industry Waste Management Practices and Procedures committing themselves to "implementing a policy goal of zero discharges of MARPOL Annex $V$ solid waste products (garbage) by use of waste minimisation procedures to significantly reduce shipboard generated waste". We must also look forward at further standards being developed by IAATO and other Antarctic tourism operators to apply as well the MARPOL standards to the special conditions of the Southern Ocean.

\section{Reception facilities}

While the provision of adequate reception facilities in all ports, including marinas and fishing harbours, for the mandatory discharge of wastes is of central importance for achieving a reduction in ship-generated waste, it is indispensable to address the economic, as well as the technical aspects of this issue if it is to be satisfactorily resolved. Article 9 of Annex IV to the Protocol on Environmental Protection to the Antarctic Treaty stipulates that parties at whose ports ships depart for or arrive from Antarctica are committed to ensuring that adequate facilities are provided to receive garbage without causing undue delay or placing inequitable burdens on countries near Antarctica.

\section{Education and awareness}

Marine debris is not only an acute environmental problem that can be solved solely by means of law enforcement and technical solutions. It is mainly a socio-economic problem originated by attitudes, behaviour, management approaches, and education 
and requiring involvement of all actors, sectors and interests, including participation of the public at large. National actions, policies and measures must be implemented; local planning and management capacity must be improved; coastal communities, the international shipping community, tourist operators and other stakeholders must raise their awareness of the challenge posed by marine debris. Regional and international cooperation must be intensified.

Initiatives such as the convening of international conferences on marine debris help to raise that awareness at the regional and global level. At the Seminar on Marine Debris on "Derelict Fishing Gear and Related Marine Debris: An Educational Outreach Seminar among APEC Partners" (Honolulu, Hawai'i, January 13-16, 2004) organized by the APEC Working Group on Fisheries (2004), Colin M. Mclff stated in the foreword "A Way Forward":

"Recognising that this problem is a regional one that requires cooperation to solve it, APEC approved a project proposal by the United States for an educational and outreach seminar on derelict fishing gear and related debris at its annual Fisheries Working Group held in Lima, Peru in 2002. The reason for choosing APEC as a potential venue for international discussion of this issue is the regional scale and multinational scope of the problem and the linkages to sustainable development, business practices, and other that cross-cut the APEC mandate and its sub-bodies (i.e. the Marine Resource, Tourism and Transportation Working Groups" (APEC, 2004).

Meetings and workshops are useful tools to raise awareness on marine debris issues but there is a need for further study, documentation and critical literature on the subject. One of the best studies on the matter has been done by UNEP (2004) in cooperation with other organizations: "Feasibility Study on Sustainable Management of Marine Litter", (UNEP, DEC. /RS.6.1.INF.9) and will be incorporated into the report of the Secretary-General of the United Nations on developments and issues relating to the oceans. On this basis the Open-Ended Informal Consultative Process on Oceans and the Law of the Sea will address as a matter of priority the challenge of marine debris to sustainable development.

At the 2004 Meeting of the Scientific Committee of CCAMLR the issue was raised of the convenience of informing the APEC sub-bodies (Marine
Resources, Tourism and Transportation Working Groups) of the measures taken by CCAMLR to avoid the impact of marine debris in the Southern Ocean. Paragraph 9.41 of the Scientific Committee's Report mentions this proposal and concludes that "these questions are within the realm of CEP". However, before making a more specific proposal on the matter to the $\mathrm{CEP}^{4}$, it appears necessary to describe the special features of the problem in the area of application of the Antarctic Treaty and its Protocol.

\section{MARINE DEBRIS AND THE ANTARCTIC MARINE ENVIRONMENT}

In order to set out the parameters that characterize the special legal and environmental characteristics of the Southern Ocean, a certain number of references are indispensable to recall:

a) Recommendation V-3: Southern Ocean ("Considering that the Southern Ocean is an integral part of the Antarctic environment and that the Consultative Governments have made substantial contributions towards knowledge of this Ocean in the Treaty area").

b) The Agreed Measures for the Conservation of Antarctic Fauna and Flora in whose Preamble the Antarctic Treaty Area is considered as a Special Conservation Area, without prejudice to the exercise of the rights of any State under international law with regard to the High Seas within the Treaty Area, namely the area south of $60^{\circ}$ South Latitude, including all ice shelves.

c) CCAMLRs' enlargement of the above mentioned area incorporating the "Antarctic marine living resources of the area between that latitude and the Antarctic Convergence, which form part of the Antarctic marine ecosystem".

d) Antarctica (defined as the area south of $60^{\circ}$ South Latitude, inclusive of ocean space) is designated by the Madrid Protocol as a "natural reserve devoted to peace and science".

We shall not dwell too much on what at first sight appears as a contradiction between the Canberra Convention setting the limit of the Antarctic marine ecosystem at the Antarctic Convergence and the

4 Committee on Environmental Protection of the Antarctic. 
Madrid Protocol, ancillary to the Washington Treaty, ratifying the validity of parallel $60^{\circ}$ South Latitude as the appropriate scope. The comprehensive protection of the Antarctic environment and dependent and associated ecosystems includes much ocean space south of $40^{\circ}$ South Latitude, and the corollary that activities that might generate pollution and marine debris within the area must be receive paramount attention when they adversely impact the Antarctic ecosystem, but their effects on areas outside the Antarctic Treaty area referred to by article 8 of Annex IV must also be taken into account.

The Antarctic legal regime for activities in Antarctic marine areas is defined by the terminology in the Preamble to the Environmental Protocol, by the key principles of Article 3, and the obligation of planning the conduct of activities to prevent marine pollution and avoid the adverse effects described in 3 (2). Planning is intended to preclude changes or critical or detrimental alterations in the marine environment, such as the distribution, abundance and productivity of marine life, threats or risks to marine species (whales, seals or Antarctic fish populations) or areas of biological, scientific or wilderness significance. It is also a cooperative approach to possible environmental emergencies foreseen in Article 15 of the Protocol. "Regular and effective monitoring" also envisaged by Article 3 is linked to compliance with the duties concerning environmental standards, informed decisions, priority awarded to scientific research and a general obligation to deter and prevent marine pollution. It is unquestionable that the presence of marine debris in the Antarctic marine environment is precisely one of the outcomes that Article 3 intends to avoid.

The mineral resource development prohibition in Article 7, preventing marine pollution by prohibiting activities, which undoubtedly could produce such pollution, also provides a strong signal against the presence of marine debris in Antarctic waters. Such a signal is supplemented by the environmental impact assessment procedures of Article 8 and Annex I. Since mining activities are prohibited, the possibilities of marine pollution by Antarctic landbased or offshore activities considerably diminish. Even so, scientific research activities involving drilling into the continental shelf could be allowed, and other marine scientific experiments require as well that their impacts be tested by the procedures established under Annex I.
Two species listed in Appendix A to Annex II, (Conservation of Antarctic fauna and flora), the Antarctic Fur Seal and the Ross Seal are accorded special protection and the Parties are thus committed to prevent any activity, including forms of marine pollution such as marine debris, which may hurt, damage or jeopardise the special protection accorded these seal species (Torres, 1990; Hucke-Gaete et al., 1997a and b). Article 4 of Annex II prohibits the introduction of alien species that might disrupt the Antarctic ecosystem: such species include not only certain non-indigenous bacteria used to ingest petroleum from oil spills but also bacteria or other microbial species transported by or contained in marine debris (Torres et al, 2003).

Article 5 (1) of Annex III pertains to the disposal of wastes at sea under three conditions: (1) the capacity of the marine environment to assimilate such wastes is taken into account; (2) the discharge is situated "wherever practicable" under conditions for "initial dilution and rapid dispersal" and (3) "large" quantities of these wastes are treated at least by maceration. During the process of adoption of the Environmental Protocol, when this article was discussed, Chile considered that the guidance it provided, under rather ambiguous and indefinite parameters, was not compatible with international standards introduced in other treaties. The norm was adopted on the assumption that more strict and detailed guidance would be generated by a substantial body of environmental impact assessments under Annex I. In any case, this provision and the prohibition in Article 7 of Annex III of certain products that could threaten the health of the Antarctic marine environment are equally incompatible with proliferation of marine debris.

Annex IV (Prevention of Marine Pollution) strengthens the jurisdictional reach of MARPOL 73/78 by incorporation into its articles 3, 5, 6, 13 and 14 . Directly relevant to the issue of marine debris is the prohibition in Article 5 of the disposal into the sea of (1) plastics, including but not limited to synthetic ropes, synthetic fishing nets, and plastic garbage bags; and (2) all forms of garbage, including paper products, rags, glass, metal. Bottles, crockery, incineration ash, dunnage, lining, and packing materials. In addition to the provision concerning reception facilities, Article 9 binds Parties to ensure that all vessels flying their flag have sufficient capacity on board for the 
retention of garbage while within the Antarctic Treaty area. Taken together, these measures, if effectively applied, would amount to a prohibition of marine debris in the Antarctic Treaty area.

In addition, Annex $\mathrm{V}$ of the Environmental Protocol provides that "any area, including any marine area" may be designated as an Antarctic Specially Protected Area (ASPA) or an Antarctic Specially Managed Area (ASMA). All these provisions should be bolstered by the establishment of Antarctica as a Special Area under the relevant Annexes to MARPOL 73/78 and further consideration as "Particularly Sensitive Area" under the IMO; application of the IMO Polar Code to navigation in Antarctic waters, the ban of industrial and nuclear waste disposal by the Basel Convention and the London Dumping Convention, perfected by its 1996 Protocol, and eventually by the consideration of Marine Protected Areas under Annex $V$ and the CCAMLR. This positive injection of international norms prohibiting pollution of the marine environment into the Antarctic legal regime is reciprocated by innovations contained in the Protocol and the advisory capabilities of the CEP under article 14 of the Protocol, including its mandate to consult and cooperate with SCAR, CCAMLR and now also with COMNAP.

Ultimately the effectiveness of international action against marine debris rests with a genuine commitment by interested States. A number of elements curtail or hamper the effectiveness of the Antarctic environmental regime, in particular with reference to the presence of marine debris. The most decisive is the lack in Antarctica of an admitted objective regime binding on third States. A secondary element is inherent to the Antarctic regime: the sovereign immunity granted in Article 11 of Annex IV and the exemption granted in Article 6 concerning sewage discharges which shall not apply if they would "unduly impair Antarctic operations". Another weakness is the lack of agreement on the urgency or the final structure of the "State of the Antarctic Environment" report and specially the scope of its extension to maritime areas. The last element in the assessment of the Antarctic treatment of issues related to marine debris is the lack of a liability regime in accordance with Article 16 as well as the absence of a procedure in accordance with Article 18 in order to settle differences concerning the application of Article 3 (Environmental Principles).

\section{CONCLUSION}

This paper addresses the complex and global character of marine debris in the oceans of the world. It recalls the special nature, fragility and uniqueness of the Antarctic marine environment, the nature of the legal regime governing Antarctica, and suggests that the CEP consider:

1. The adoption of a measure, resolution or decision concerning the problem of marine debris, including a certain number of actions intended to minimise and reduce its adverse impact on the Antarctic marine ecosystem.

2. To request IAATO and Antarctic tour operators to exert the greatest care and concern, and develop a code of conduct for their vessels to effectively prevent all forms of marine litter while travelling in Antarctic waters during the Austral summer.

3. To support CCAMLR to sustain, improve and expand monitoring actions undertaken at CEMP sites in accordance with its Ecosystem Monitoring and Observers Programmes.

4. Consider the inclusion of a substantive section on marine debris in any future State of the Environment report.

5. Recommend the development of educational strategies and outreach actions, taking into account the experience obtained by international bodies such as APEC, CCAMLR, FAO, GPA, Marine Pollution Monitoring Management Group, PACON International, UNEP's Regional Seas Programmes and taking into account the important opportunity provided by the International Polar Year.

6. Consider the inclusion of a special section in the ATCM's Final Report that would be commended for consideration by the UN Secretary General and as a contribution to discussions to be held at the annual United Nations Open-ended Informal Consultative Process on Oceans and the Law of the Sea.

\section{ADDENDA}

In the Final Report of the VIII Meeting of the CEP (CEP, 2005) in the Item 4: Compliance with the Protocol on Environmental Protection, 4f) Matters covered by Annex IV (Prevention of Marine Pollution) it was stated the following paragraphs: 
"(155) Chile introduced ATCM XXVIII/WP052 Marine Debris: Global and Regional Impacts, outlining the harmful effects of marine debris and suggesting measure to prevent and reduce marine debris, which is a complex issue of global concern. The paper included several items for the Committee's consideration.

(156) IAATO shared Chile's concerns regarding marine debris but, in response to the recommendation that IAATO tour operators develop a code of conduct for their vessels, indicated that all of its members follow IAATO standard operating procedures for ship activities, which specifically prohibit any dumping of waste or any other products. This is consistent with the Protocol, is documented in all operators' EIAs and exceeds the requirements of MARPOL V. IAATO does not, therefore, see the need for further codes of conduct, which in any case should be applied to all vessels, not just tour operators.

(160) In response to Chile's other recommendations, the Committee agreed to note, with particular regard to the requirements of Article 5, Annex IV:

that marine debris is an issue warranting the attention of Antarctic national operators and tour operators;

that CCAMLR should be supported in sustaining, improving and expanding its monitoring of debris;

that consideration should be given to including a section on marine debris in any future State of the Environment Report; and

that there would be value in the development of educational strategies and actions, taking into account the International Polar Year".

\section{LITERATURE CITED}

Aguilera C. \& D. Torres 2004. Desechos marinos recolectados en cabo Shirreff, isla Livingston, durante las temporadas antárticas 2002/2003 y 2003/2004. Boletín Antártico Chileno, 24(1):12-14

APEC, 2004. Derelict Fishing Gears and Related Marine Debris: An Educational Outreach Seminar Among APEC Partners. Hawai'i, January 13-16, 2004

CEP, 2005. Report of the Committee for Environmental Protection, CEP VIII. Stockholm 6-10 June 2005. Pagés 1-31 + Anexe 7
CCAMLR, 2004. SC-CCAMLR-XXIII. Report of the Twenty-third Meeting of the Scientific Committee. Hobart, Australia, 25-29 October 2004

GESAMP, 2001. Protecting the oceans from landbased activities. Study № 71:15-26

Hucke-Gaete, R., D. Torres \& V. Vallejos 1996. Enmallamiento de Arctocephalus gazella en cabo Shirreff, isla Livingston, Antártica, 1988-1996. 7a Reunión de Trabajo de Especialistas en Mamíferos Marinos Antárticos de América del Sur. Primer Congreso de la Sociedad Latinoamericana de Especialistas en Mamíferos Acuáticos. Viña del Mar, 2225 de octubre de 1996, Chile. Resumen en Serie Científica. INACH 46:177

Hucke-Gaete, R. D. Torres \& V. Vallejos 1997a. Entanglement of Antarctic fur seals in marine debris at Cape Shirreff and San Telmo Islets, Livingston Island, Antarctica: 1988-1997. SC- CAMLR-XVI/BG/33. 27 October 1997, Hobart, Australia. Resumen en Serie Científica INACH, 47:167

Hucke-Gaete, R., D. Torres \& V. Vallejos 1997 b. Entanglement of Antarctic fur seals, Arctocephalus gazella, by marine debris at Cape Shirreff and San Telmo Islets, Livingston Island, Antarctica: 1988-1996. Serie Cientifica INACH, 47:123-135

PACON, 2000. Origins, Type, Distribution and Magnitude of Derelict Fishing Gear. Proceedings of the Fourth International Marine Debris Conference on Derelict Fishing Gear and the Marine Environment. Hawai'i, 5 -9 June 2000

Sheavly, S.B., 2004. Marine Debris: an Overview of a Critical Issue for our Oceans. Proceedings of the International Clean-Up Conference, May 14-18, 2004. San Juan, Puerto Rico

Torres, D., 1990. Collares plásticos en lobos finos antárticos. Otra evidencia de contaminación. Boletín Antártico Chileno, 10(1):20-22

Torres, D., 1992. Synthesis of the environmental impact studies at Cape Shirreff, Livingston Island, Antarctica. In: International Seminar "Science in Antarctica". Universidad de Chile, National Science Foundation, Universidad de Magallanes, Punta Arenas, Chile, 12-16 April 1992, 8 págs. 
Torres, D. 1996. Antecedentes y sugerencias para establecer una línea de acción conjunta para el seguimiento de la conservación ambiental en la Antártica. Págs.15-21 En: Seminario "Protección de los Ecosistemas Americano y Antártico. Centro Austral Antártico, Universidad de Magallanes, 27 - 28 de marzo de 1995, Punta Arenas, Chile. 152 pp.

Torres, D. 1997. Sugerencias para minimizar la contaminación marítima con desechos plásticos de fuera del Área del Tratado Antártico. Boletín Antártico Chileno, 16(1):13-17

Torres, D. 2000. Cuarta Conferencia Internacional sobre Desechos Marinos. Boletín Antártico Chileno, 19(2):33-35

Torres, D. 2001. Reunión PACON International: El tema de los desechos marinos. Boletín Antártico Chileno, 20(2):29-31

Torres, D. \& A. Aguayo 1993. Impacto antrópico en cabo Shirreff, isla Livingston, Antártica. Serie Científica. INACH, 43:93-108

Torres, D. \& M. Gajardo 1985. Información preliminar sobre desechos plásticos hallados en cabo Shirreff, isla Livingston, Shteland del Sur. Boletín Antártico Chileno 5(2):12-13

Torres, D. \& D. Jorquera 1994. Marine debris analysis collected at Cape Shirreff, Livingston Island, South Shetland, Antarctica. Serie Científica INACH, 44:81-86

Torres, D. \& D. Jorquera 1995. Línea de base para el seguimiento de los desechos marinos en cabo Shirreff, isla Livingston, Antártica. Serie científica. INACH, 45:131-141
Torres, D. \& D. Jorquera 1996.Monitoring results of marine debris at Cape Shirreff, Livingston Island, South Shetland Islands, during the Antarctic season 1995/96. Serie científica. INACH, 46:121-132

Torres, D. \& D. Jorquera 1998. Results of synthesis of marine debris survey carried out at Cape Shirreff, Livingston Island in the austral summer 1997/98. CCAMLR-XVII/BG/27. CCAMLR Scientific Abstracts 1998. Resumen en Serie Científica. INACH, 48

Torres, D., D. Jorquera, M. García \& V. Vallejos 1996. Liberación de lobos finos, Arctocephalus gazella, enmallados en cabo Shirreff e islotes San Telmo, isla Livingston, Antártica. Boletín Antártico Chileno, 15(2):7-10

Torres, D, D. Jorquera, V. Vallejos, R. Hucke-Gaete \& S. Zárate 1997. Beach debris survey at Cape Shirreff, Livingston Island, during the Antarctic season 1996/97. Serie Científica. INACH, 47:137-147

Torres, D., D. Jorquera, V. Vallejos, R. HuckeGaete \& S. Zárate 1997. Beach debris survey at Cape Shirreff, Livingston Island, during the Antarctic season 1996-97. CCAMLRXVI/BG/35. 27 October, 1997, Hobart, Australia. Resumen en Serie Científica. INACH, 47:166

UNEP, 2004. Feasibility Study on Sustainable Management of Marine Litter, UNEP, DEC./ RS.6.1.INF.9 
Esta edición se terminó de imprimir en noviembre de 2011, en los talleres de La Prensa Austral IMPRESOS.

Fono: 204012 / Fax: 247406 / Waldo Seguel 636

\author{
Punta Arenas - Chile
}

